\title{
TOWARD A NATIONAL RESILIENCE FUND
}

\begin{abstract}
COVID-19's economic impact has been catastrophic for state and local governments. By Federal Reserve estimates, income and sales revenues will have declined by over $\$ 50$ billion in fiscal year 2020 and may decline by as much as $\$ 137$ billion in 2021 . Pandemics are, of course, not the only catastrophic risks we may face in coming years. Financial crises, natural disasters, social justice crises, and climate change-related catastrophes all present serious risks, and often have a compounding effect on one another. These risks are especially salient for state and local governments, which are at the forefront of crisis response. A government's legitimacy is tested and measured by its ability to respond to these challenges, but existing state and local financial frameworks have proven too thin and brittle to absorb shocks like COVID-19 or the Financial Crisis of 2007. This Essay describes how a national resilience fund, with subaccounts created for each state and territory, would strengthen the ability of state and local governments to respond to crises that will likely arise in the coming years. A national resilience fund could be based on a familiar, flexible structure that has been used for decades: the Unemployment Trust Fund. Such a structure would help insulate the resilience fund from local political pressures yet would have the financial strength to help state and local governments absorb the costs associated with severe crises such as pandemics and natural disasters, thereby helping to preserve the government's legitimacy in times of severe social stress.
\end{abstract}

AUTHOR-Robert J. Watkins/Procter \& Gamble Professor of Law, Ohio State University Moritz College of Law. Thanks to Sam Mallory for excellent research assistance and to Cinnamon Carlarne and Diego Lopez for helpful comments on an earlier draft. Thanks also to the Northwestern University Law Review Online staff for their outstanding editorial work. 
N ORTHW ESTER N UNIVERS IT Y L A W REVIEW ONLINE

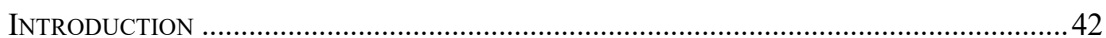

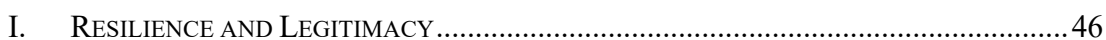

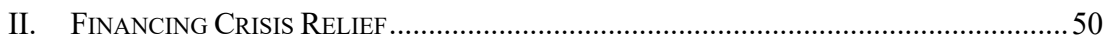

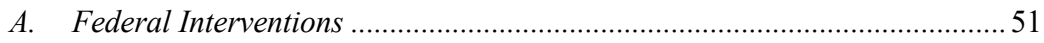

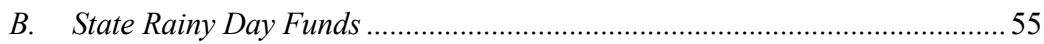

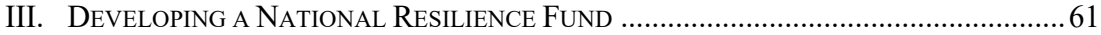

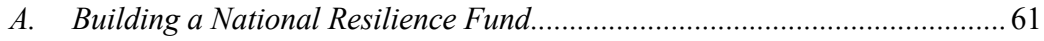

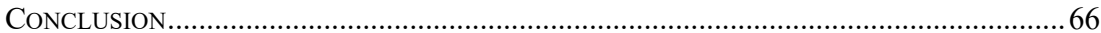

\section{INTRODUCTION}

COVID-19's economic impact will reverberate throughout the country for years to come. Estimates suggest that global government deficits could be as high as $\$ 30$ trillion by $2023 .{ }^{1}$ The pandemic has severely impacted every state and city in the United States - most importantly through loss of life but also through decreased economic prospects. ${ }^{2}$ Reduced economic activity will negatively impact public services as tax revenues decrease and thereby limit state and local governments' ability to provide their typical services including health care, public safety services, and public sector

1 COVID-19: Briefing Note \#10: June 18, 2020, MCKINSEY \& Co. (June 18, 2020), https://www.mckinsey.com/business-functions/risk/our-insights/covid-19-implications-for-business [https://perma.cc/ND5T-F4EC]. As a point of comparison, this was roughly the combined market value of all publicly traded U.S. firms at the end of 2018. Total Market Value of U.S. Stock Market, SiBLIS RSCH., https://siblisresearch.com/data/us-stock-market-value/ [https://perma.cc/KTR7-P2NX] (reporting an approximate value of $\$ 30,102,771,200,000)$.

2 This is not to suggest that all countries will suffer from COVID-19 equally, just that all countries will experience serious loss as a result of the pandemic. As IMF analyst Gita Gopinath notes:

This is a truly global crisis as no country is spared. Countries reliant on tourism, travel, hospitality, and entertainment for their growth are experiencing particularly large disruptions. Emerging market and developing economies face additional challenges with unprecedented reversals in capital flows as global risk appetite wanes, and currency pressures, while coping with weaker health systems, and more limited fiscal space to provide support. Moreover, several economies entered this crisis in a vulnerable state with sluggish growth and high debt levels.

Gita Gopinath, The Great Lockdown: Worst Economic Downturn Since the Great Depression, IMFBLOG (Apr. 14, 2020), https://blogs.imf.org/2020/04/14/the-great-lockdown-worst-economic-downturn-sincethe-great-depression/ [https://perma.cc/86CH-RETQ]. 
employment. ${ }^{3}$ The resulting human costs are difficult to quantify, but are clearly not limited to those directly affected by the virus. ${ }^{4}$

Pandemics are, of course, not the only catastrophes we will face in the coming years. Financial crises, natural disasters, and catastrophic climate change-related events all present serious risks. ${ }^{5}$ These risks are especially salient for state and local governments, which are "at the forefront of the response... in their communities and will likely need to increase their typical spending to provide crucial public health services." ${ }^{6}$ Austerity is a poor plan for long-term economic health, as reduction in services by state and local governments can be "a substantial restraint on the vigor of the

\footnotetext{
3 It has been suggested that COVID-19 may have a positive effect on climate change due to a reduction in pollution associated with decreased economic activity. A study in Nature Climate Change suggests that daily fossil $\mathrm{CO}_{2}$ emissions during periods of forced confinement will range from $-11 \%$ to 25\%. Corinne Le Quéré, Robert B. Jackson, Matthew W. Jones, Adam J.P. Smith, Sam Abernethy, Robbie M. Andrew, Anthony J. De-Gol, David R. Willis, Yuli Shan, Josep G. Canadell, Pierre Friedlingstein, Felix Creutzig \& Glen P. Peters, Temporary Reduction in Daily Global $\mathrm{CO}_{2}$ Emissions During the COVID-19 Forced Confinement, 10 NATURE Climate Change 647, 652 (2020). However, the study also notes that the "associated annual decrease will be much lower $(-4.2$ to $-7.5 \%$ according to our sensitivity tests), which is comparable to the rates of decrease needed year-on-year over the next decades to limit climate change to a $1.5^{\circ} \mathrm{C}$ warming.". Id. Similarly, the World Health Organization (WHO) reports reduced economic activity and temporary improvements in air quality in some areas resulting from efforts to control the pandemic but persistence of carbon dioxide and other greenhouse gases. Coronavirus Disease (COVID-19): Climate Change, World Health ORg. (Apr. 22, 2020), https://www.who.int/news-room/q-a-detail/q-a-on-climate-change-and-covid-19

[https://perma.cc/SB2W-J235]. The reductions associated with forced confinement have only a limited effect on overall atmospheric concentrations of $\mathrm{CO}_{2}$. Id . Additionally, even with the lockdown, $\mathrm{CO}_{2}$ levels in the first months of 2020 have been higher than 2019. Id. A rapid restart to the economy may also create an emissions spike "unless there is a clear focus to promote equity, environmental health, around a just transition to a green economy." Id.

${ }^{4}$ In comparison to the Financial Crisis, which resulted in a global reduction of $0.1 \%$ in 2009 real gross domestic product (GDP) growth, the "Great Lockdown" is expected to result in a $3 \%$ GDP reduction, making it the "worst recession since the Great Depression, and far worse than the Global Financial Crisis." Gopinath, supra note 2. And while world economies may recover quickly once the pandemic is controlled, the cumulative loss to global GDP in 2020 and 2021 alone may be around $\$ 9$ trillion - the approximate size of the economies of Germany and Japan combined. Id.; see also INT'L MONETARY FUND, WORLD ECONOMIC OUTLOOK: THE GREAT LOCKDOWN 5 (2020), https://www.imf.org/en/Publications/WEO/Issues/2020/04/14/weo-april-2020 [https://perma.cc/Z372-9 PMZ] (projecting global growth impacts "far worse than during the 2009 global financial crisis").

${ }^{5}$ The winter storm power crisis in Texas highlights these risks and their attendant danger to governmental legitimacy. See, e.g., Brad Plumer, A Glimpse of America's Future: Climate Change Means Trouble for Power Grids, N.Y. TIMES (Mar. 12, 2021), https://www.nytimes.com/2021/02/16/ climate/texas-power-grid-failures.html [https://perma.cc/3SSP-R7G7] (detailing the risks that climate change poses to power grids across the United States).

${ }^{6}$ Louise Sheiner \& Sophia Campbell, How Much Is COVID-19 Hurting State and Local Revenues?, BROOKINGS (Sept. 24, 2020), https://www.brookings.edu/blog/up-front/2020/09/24/how-much-is-covid19-hurting-state-and-local-revenues/ [https://perma.cc/N6B6-R4PA].
} 
NORTHWESTERN UN IVERSITY LA W REVIEW ONLINE

economic recovery." 7 As noted in a McKinsey report, during the Great Recession:

Despite enlisting their full arsenal of austerity measures, states were pushed to a breaking point by the cumulative burden.... Others cut elementary- and secondary-education funding by as much as 40 percent, leading many districts to reduce the number of school days and furlough employees. Between 2008 and 2013, state-government workforces were reduced by about 6 percent, and the average state-pension funding ratio fell to 75 percent. And, even though the federal government injected about $\$ 1.3$ trillion into the economy as part of the largest fiscal recovery plan in US history (at the time), states were still left with challenging decisions. ${ }^{8}$

Perhaps even more importantly, a reduction in vital services can also expose and exacerbate inequality, further eroding confidence in governmental institutions and wearing away the government's legitimacy in a moment already fraught with challenges. ${ }^{9}$

This Essay sets out the need for a robust public fund to bridge state and local financial gaps in times of crisis. Such a tool, operating within a federalist framework, would allow states to draw from the fund to meet state and local financing needs. ${ }^{10}$ Part I discusses the importance of maintaining

${ }^{7} I d$. In the wake of the Financial Crisis of 2007, instead of attempting to stimulate the economy, European countries generally attempted to reduce government spending -implementing strict "austerity" policies - that resulted in stunted economic growth and adverse health outcomes. Martin McKee, Marina Karanikolos, Paul Belcher \& David Stuckler, Austerity: A Failed Experiment on the People of Europe, 12 CliniCAL MED. 346, 346 (2012); Nadia Daar \& Nona Tamale, A Virus of Austerity? The COVID-19 Spending, Accountability, and Recovery Measures Agreed Between the IMF and Your Government, OXFAM INT'L (Oct. 12, 2020), https://www.oxfam.org/en/blogs/virus-austerity-covid-19-spendingaccountability-and-recovery-measures-agreed-between-imf-and [https://perma.cc/MCE9-642M].

8 Trey Childress, Ian Jefferson, Aly Spencer \& Todd Wintner, The State Transformation Mandate During COVID-19, MCKINSEY \& Co. (June 15, 2020), https://www.mckinsey.com/industries/publicsector/our-insights/the-state-transformation-mandate-during-covid-19\# [https://perma.cc/9G8E-UUXT].

9 As an example, public services spending cuts associated with austerity measures have created concerns of a "lost decade" with rising inequality and poverty. TERESA CAVERO \& KRISNAH POINASAMY, A Cautionary Tale: The True Cost of Austerity and Inequality in Europe 3 (2013), https://www-cdn.oxfam.org/s3fs-public/file_attachments/bp174-cautionary-tale-austerity-inequalityeurope-120913-en_1_1.pdf [https://perma.cc/XA4K-FMY5].

10 There are numerous national funds already managed by the federal government, and some have called for a national sovereign development fund. The most thorough and convincing case for such a fund is made by Saule Omarova and Robert Hockett. See generally Robert C. Hockett \& Saule T. Omarova, Private Wealth and Public Goods: A Case for a National Investment Authority, 43 J. CORP. L. 437 (2018) (describing and advocating for the creation of a "National Investment Authority"). While a sovereign development fund may serve an important role in helping to manage long-term risks and transition costs associated with climate change (among other concerns), it would not be as effective in helping to absorb short-term systemic shocks. This is because sovereign development funds typically invest in less liquid projects such as infrastructure projects. Indeed, the raison d'être of a sovereign development fund is longterm investment in public-goods projects that tend to not have sufficient private investment interest. See 
key social services in order to preserve governmental legitimacy, particularly in times of crisis. This Part argues first that the ability to manage these crises is essential to upholding the social contract. Second, it explains that the high probability of future crises necessitates additional financial preparation at the federal level through a dedicated public fund.

In Part II, the Essay describes the various interventions that have been used to mitigate the effects of the COVID-19 pandemic - the most recent major test of governmental financial resiliency. ${ }^{11}$ At the federal level, the CARES Act attempted to provide some support to state and local governments, and the Federal Reserve and other central banks have also established a variety of programs to help support economies during the crisis. ${ }^{12}$ At the state level, rainy day funds helped manage some of the pandemic's budgetary impacts. ${ }^{13}$ However, these measures have proven to be inadequate. The primary CARES Act support mechanism for state and local governments - the Municipal Liquidity Facility - has not operated as planned. ${ }^{14}$ Moreover, most existing state rainy day funds have already been drained. ${ }^{15}$ With the end of the pandemic not yet in sight, more climate and public health disasters are sure to come before these funds can be replenished.

Unlike these ad hoc interventions, an ex ante national resilience fund, if properly structured, will ensure that resources can be deployed faster than through ex post legislation. This would allow state and local governments to potentially avoid or minimize some of the risks associated with a major catastrophe. Because these funds are established ex ante, they are built into the government's budget structure through the legislative process. ${ }^{16}$ By contrast, ex post legislation borrows from future generations who do not have the ability to vote on the imposition of the debt.

Part III sketches out the possibility of a national fund and reintroduces a proposal modeled after the Unemployment Trust Fund. This fund, which I label a "national resilience fund," would help state and local governments

\footnotetext{
HÅvard Halland, Michel NoËl, Silvana Tordo \& Jacob J. Kloper-Owens, Strategic InVESTMENT FundS: OpPoRTunities AND Challenges 2, 16-17 (World Bank, Pol'y Rsch., Working Paper No. 7851, 2016), http://documents.worldbank.org/curated/en/235311475681523659/pdf/WPS78 51.pdf [https://perma.cc/YXT2-AHV8].

11 See infra notes 70-82 and accompanying text.

12 Sheiner \& Campbell, supra note 6 (explaining CARES Act funding and the Federal Reserve's Municipal Liquidity Facility).

13 See infra notes 70-82 and accompanying text.

14 See infra notes 54-67 and accompanying text.

15 See infra notes 87-92 and accompanying text.

16 This point should not diminish the importance of ex ante preparations of other types, including investment in, for example, initiatives to reduce inequality or adapt to changing climate conditions.
} 
manage severe short-term crises, such as pandemics and natural disasters, by providing the financial resources necessary to maintain essential public services while responding to the crisis. This assistance has two key benefits. First, it helps governments sustain mitigation efforts that may help prevent significant future costs. ${ }^{17}$ Second, maintenance of services allows governments to maintain legitimacy and public trust in times of crisis.

\section{RESILIENCE AND LEGITIMACY}

The government's authority to govern - and the corresponding willingness of the citizenry to obey - is based on "a belief by virtue of which persons exercising authority are lent prestige." 18 This belief in government authority is premised on both its power to exert that authority, as well as on the maintenance of its social contract with citizens. ${ }^{19}$ The social contract implicitly comes with an expectation that the government will exercise its authority in a way that secures basic services for its people, ${ }^{20}$ including

\footnotetext{
17 The benefit of early mitigation efforts in a crisis such as a pandemic can be seen with the use of the WHO's "Contingency Fund for Emergencies," created after the 2014 Ebola crisis. Comparing the 2014 Ebola outbreak in West Africa, which triggered formation of the Contingency Fund for Emergencies (CFE), with the 2017 outbreak in Congo the CFE subsequently helped to manage, the WHO states:

The contrast between the 2017 Democratic Republic of the Congo Ebola outbreak and the 2014 West Africa Ebola epidemic is stark. The former claimed four lives, lasted two months, and cost US [\$]2 million to contain. The latter claimed more than 11000 lives over almost two years, at a cost of more than US [\$]3.6 billion. Clearly no single factor can account for such a vast disparity in mortality and morbidity between two outbreaks. But equally, there can be no doubt that the speed of the response in the Democratic Republic of the Congo was the decisive factor in the swift containment of the outbreak - something that would simply not have been possible without the CFE.

World Health ORg., CONTINGency Fund for EMERgencies: Enabling Quick ACtion to SAVE LIVES 5 (2018), https://www.who.int/emergencies/funding/contributions/cfe-impact-report-web2018.pdf ?ua $=1$ [https://perma.cc/TFX4-YXGW].

18 MaX Weber, The Theory of Social and Economic Organization 382 (Talcott Parsons ed., A.M. Henderson \& Talcott Parsons trans., 2009); see also Fabienne Peter, Political Legitimacy, STAN. ENCYC. PHIL. (Apr. 24, 2017), http://plato.stanford.edu/entries/legitimacy/ [https://perma.cc/2HQ2$6 \mathrm{~K} 2 \mathrm{C}$ ] (explaining some of the various conceptions of, and debates surrounding, political legitimacy).

19 See generally ThOMAs HobBes, LeViathan (Edwin Curley ed., 1994) (discussing the structure of society and idea of a legitimate government under a social contract theory). A social contract theory was articulated by Thomas Hobbes in his 1651 work Leviathan and has been expanded and debated by political philosophers such as Locke, Rousseau, Kant, and Rawls among many others. Fred D'Agostino, Gerald Gaus \& John Thrasher, Contemporary Approaches to the Social Contract, STAN. ENCYC. PHIL. (May 31, 2017), https://plato.stanford.edu/entries/contractarianism-contemporary/ [https://perma.cc/5W 7P-MY5H].

20 See WORLD BANK GRP., WORLD DEVELOPMENT REPORT 2017: GOVERNANCE AND THE LAW 31 (2017) ("When a government repeatedly delivers on its commitments, it legitimizes itself, such as by reliably providing public services.").
} 
services supporting social order. ${ }^{21}$ As described by Clark and Monk, "state legitimacy depends upon the extent to which government meets the fundamental interests of its citizens, and the extent to which it can claim a sphere of autonomy." ${ }^{22}$ In order to maintain legitimacy with its citizens, it is pivotal that a government be able to provide key services during crises, during which an extensive use of government resources - including direct health care, medical equipment, and health infrastructure-is especially required to develop long-term solutions to the crisis. A natural disaster, for example, requires resources and coordination to reestablish "community lifelines," including food, clean water, and medical care. ${ }^{23}$ By contrast, when the government fails to provide that "fundamental interest" and is perceived as illegitimate, societies frayed by pandemics or racial injustice may completely unravel. ${ }^{24}$

Crises - even pandemics, which by definition affect societies around the world - typically require extensive local and state management. While the legitimacy of the federal government may be impacted by its response to crises, state and local governments typically shoulder the burden of disaster with the federal government providing a supporting role. As described by Federal Emergency Management Agency (FEMA),

Disasters always occur at the local level. For some types of natural disasters, like slow rising floods or approaching hurricanes, warning is available. Other disasters, like earthquakes, happen with little or no warning. The citizens in the area where the event occurs and their local governments and voluntary agencies are the first to have to cope with the damage. ${ }^{25}$

${ }^{21}$ Philip Pettit, Legitimacy and Justice in Republican Perspective, 65 CURRENT LEGAL PROBS. 59, 65 (2012).

22 Gordon L. Clark \& Ashby Monk, Government of Singapore Investment Corporation (GIC): Insurer of Last Resort and Bulwark of Nation-State Legitimacy, 23 PAC. REV. 429, 431 (2010).

${ }^{23}$ Under the National Response Framework, providing community lifelines ensures "continuous operation of critical government and business functions and is essential to human health and safety or economic security.” U.S. DEP'T OF HOMELAND SeC., NATIONAL RESPONSE FRAMEWORK 8 (4th ed. 2019). Community lifelines include safety and security; food, water, shelter; health and medical services; energy (power \& fuel); communications; transportation; and hazardous material. Id.

24 The protests following the killing of George Floyd illustrate this fraying of American governmental legitimacy. As discussed by Patrick Eddington, "the longstanding and ongoing targeting of [B]lack Americans by that still white-dominated power structure ... has brought the country to a place where people of color increasingly see American governmental institutions as corrupt, unaccountably violent, and thus illegitimate." Patrick G. Eddington, Race, Violence, and Political Illegitimacy, DEFENDING RTS. \& DISSENT (June 10, 2020), https://rightsanddissent.org/news/race-violence-andpolitical-illegitimacy/ [https://perma.cc/F9JQ-YH57].

25 Fed. Emergency Mgmt. Agency, State Disaster Management Course - IS 208, at 3.4, https://training.fema.gov/emiweb/downloads/is208sdmunit3.pdf [https://perma.cc/X9E9-6PCM]. 
However, local governments typically cannot marshal the resources necessary to manage catastrophes such as pandemics and natural disasters. ${ }^{26}$ Furthermore, local governments usually cannot directly access federal programs. ${ }^{27}$ State governments are essential intermediaries between the federal and local governments; they are large enough to marshal resources but also more localized and responsive to local needs, more knowledgeable of available local resources, and arguably more accountable to local voters than federal governments. As noted by James Madison in Federalist No. 45, this notion of state control is grounded in the American federalist system, in which "[t]he powers reserved to the several States will extend to all the objects which, in the ordinary course of affairs, concern the lives, liberties, and properties of the people, and the internal order, improvement, and prosperity of the State." ${ }^{28}$ Because of this federal system-and the supporting role that FEMA and other government agencies provide in times of severe crisis - the federal government's legitimacy is inextricably linked to the operation and resiliency of state and local governments.

That local, state, and federal governmental legitimacy will be tested in the coming years is underscored by four current intersecting crises: the COVID-19 pandemic, the racial justice crisis, economic dislocation due to globalization, and the climate crisis. All of these crises are expected to continue and even worsen, ${ }^{29}$ resulting in major societal impacts that will require strong responses and transformative efforts at both the state and local levels.

Future crises may not be entirely predictable in both timing and magnitude, but pandemics, economic crises, and climate-related disasters are nonetheless highly probable events. ${ }^{30}$ The current COVID-19 pandemic and

\footnotetext{
${ }^{26}$ See infra notes 77-89 and accompanying text.

27 FED. EMERGENCY MGMT. AGENCY, supra note 25, at 3.6.

28 The Federalist No. 45 (James Madison).

29 See, e.g., Henry Fountain, Climate Change Is Accelerating, Bringing World 'Dangerously Close' to Irreversible Change, N.Y. TIMES (Feb. 16, 2021), https://www.nytimes.com/2019/12/04/climate/ climate-change-acceleration.html [https://perma.cc/FA2R-WYYW] (describing how the climate crisis will continue to worsen); Nina Lakhani, Killer Heat: US Racial Injustices Will Worsen as Climate Crisis Escalates, GuARDIAN (July 28, 2020, 5:00 PM), https://www.theguardian.com/us-news/2020/jul/28/usracial-injustices-will-worsen-climate-crisis-escalates [https://perma.cc/5FUG-2HN8].

${ }^{30}$ For example, noting at least two influenza pandemics in each of the past three centuries, Hill, Tildesley, and House argue that "[b]eing prepared to experience several pandemics a century could ensure a quicker, cheaper and more efficient response to the threat posed by this disease." Edward Hill, Michael Tildesley \& Thomas House, How Predictable Are Flu Pandemics?, 14 Significance 28, 29 tbl.1, 33 (2017). Similarly, historical evidence suggests that the economic system is "vulnerable to predictable boom-bust cycles driven by credit expansion and asset price growth." Robin Greenwood, Samuel G. Hanson, Andrei Shleifer \& Jakob Ahm Sørensen, Predictable Financial Crises 32 (Nat'l Bureau of Econ. Rsch., Working Paper No. 27396, 2020). As a result, the authors argue that "policymakers should consider prophylactic policy interventions that lean against the wind." Id.
} 
climate-related crises provide evidence of both the probability of future crises as well as evidence of the ways in which these crises challenge government legitimacy, especially when basic services that protect citizen health and safety are in short supply.

For example, New York City Mayor Bill de Blasio's concerns about the city's ability to provide basic services threatened city government legitimacy. De Blasio stated that given the likely $\$ 10$ billion deficit related to COVID-19 in New York's budget over 2020 and 2021, New York City would not be able to "provide basic services and actually have a normal society." ${ }^{11}$ De Blasio's initial handling of the COVID-19 pandemic has drawn sharp criticism from New Yorkers and onlookers alike who question whether the city's government was equipped to handle such a crisis. ${ }^{32}$

Another example can be drawn from the recent fires in California. Despite extensive local government preparation for wildfires, the state government of California had to request additional emergency resources from other states and the federal government during this past year's catastrophic fires. ${ }^{33}$ The strain on California's mutual aid system resulting from the fires made it difficult for state and local governments to get firefighting resources, both in- and out-of-state, to fight the fires. ${ }^{34}$

It is the high probability of future crises that justifies planning and mitigation and distinguishes them from "Black Swan" events, a term popularized by Nassim Nicholas Taleb intended to refer to outlier events for which no government could plan. ${ }^{35}$ Indeed, the COVID-19 pandemic, while

\footnotetext{
31 Sarah Hansen, Coronavirus Crisis Has Cost NYC up to \$10 Billion: 'Basic Services' at Risk as De Blasio Pleads for More Federal Aid, ForBes (Apr. 15, 2020, 11:21 AM), https://www.forbes.com/sites/ sarahhansen/2020/04/15/coronavirus-crisis-has-cost-nyc-up-to-10-billion-basic-services-at-risk-as-deblasio-pleads-for-more-federal-aid/?sh=5892e67647a1 [https://perma.cc/68WY-B2B2].

32 See David Freedlander, When New York Needed Him Most, Bill De Blasio Had His Worst Week as Mayor, N.Y. MAG.: INTELLIGENCER (Mar. 26, 2020), https://nymag.com/intelligencer/2020/03/billde-blasio-had-his-worst-week-as-new-york-city-mayor.html [https://perma.cc/S6TN-UDNB]; Charles Duhigg, Seattle's Leaders Let Scientists Take the Lead. New York's Did Not, New YORKER (Apr. 26, 2020), https://www.newyorker.com/magazine/2020/05/04/seattles-leaders-let-scientists-take-the-leadnew-yorks-did-not [https://perma.cc/2FML-E5AH]; Jeffery C. Mays \& Joseph Goldstein, Mayor Resisted Drastic Steps on Virus. Then Came a Backlash from His Aides., N.Y. TIMES (Sept. 10, 2020), https://www.nytimes.com/2020/03/16/nyregion/coronavirus-bill-de-blasio.html [https://perma.cc/3AYA $-\mathrm{N} 7 \mathrm{QJ}]$.

33 See Taryn Luna, California Firefighting Resources 'Stretched' by 23 Major Wildfires, Newsom Says, L.A. TIMES (Aug. 19, 2020, 8:18 PM), https://www.latimes.com/california/story/2020-08-19/ california-resources-stretched-23-wildfires [https://perma.cc/S9PU-VV3H].

${ }^{34} \mathrm{Id}$.

35 In his 2007 book The Black Swan, Nassim Nicholas Taleb popularized the term "Black Swan event," which refers to a catastrophic event with three key attributes:
} 
certainly a catastrophe by any calculation, was not an unpredictable event. ${ }^{36}$ The risk of a global pandemic was not only contemplated; it was expected. ${ }^{37}$ As a New Yorker article put it, the pandemic was "wholly predictable[Taleb], like Bill Gates, Laurie Garrett, and others, had predicted it—a white swan if ever there was one." ${ }^{38}$

When governments face crises such as climate-related disasters, societal upheavals in response to injustice, pandemics, and economic dislocation, they will need to be financially prepared to quickly and effectively mitigate negative impacts. A resilience fund may, like other types of reserve funds, function as a "bulwark of nation-state legitimacy" ${ }^{39}$ by enabling a state to insulate itself against economic instability, in key part by bridging existing rifts and chasms between federal, state, and local resources and responses. Moreover, as these events often have compounding effects that reinforce and exacerbate one another, the need for a more resilient public finance structure has never been greater.

\section{FINANCING CRISIS RELIEF}

At the core of any successful crisis response, whether to a pandemic, a natural disaster, or an economic crisis, is a robust legal and financial framework that can quickly deploy funds to support relief efforts and rebuild the economic infrastructure..$^{40}$ This Part first describes some of the federal interventions used to mitigate catastrophes affecting state and local governments. It also explains why these interventions have largely been inadequate for COVID-19's demands and will likely be inadequate in the

First, it is an outlier, as it lies outside the realm of regular expectations, because nothing in the past can convincingly point to its possibility. Second, it carries an extreme impact .... Third, in spite of its outlier status, human nature makes us concoct explanations for its occurrence after the fact, making it explainable and predictable.

Nassim Nicholas Taleb, The Black Swan: The Impact of the Highly Improbable xxii (2d ed. 2010).

36 Bernard Avishai, The Pandemic Isn't a Black Swan but a Portent of a More Fragile Global System, NEW YORKER: DAILY COMMENT (Apr. 21, 2020), https://www.newyorker.com/news/daily-comment/the -pandemic-isnt-a-black-swan-but-a-portent-of-a-more-fragile-global-system [https://perma.cc/9VAC6XK5] (quoting Taleb from an interview in which he stated, "[w]e issued our warning that, effectively, you should kill [COVID-19] in the egg").

${ }^{37} \mathrm{Id}$.

${ }^{38} I d$.

${ }^{39}$ Clark \& Monk, supra note 22.

40 See, e.g., Dalvinder Singh \& John Raymond LaBrosse, Developing a Framework for Effective Financial Crisis Management, 2011 OECD J.: FIN. MKT. TRENDS 125, 129-30 (2012) (noting that, for example, a central bank must provide liquidity "decisively and quickly without hesitation, otherwise a panic could be prolonged and spread into other parts of the financial system which were unaffected by the original problem"). 
face of expected future catastrophes. Second, this Part details state "rainy day funds" and why they are also insufficient in the face of a widescale crisis.

\section{A. Federal Interventions}

Federal crisis interventions are primarily ad hoc efforts that may not occur until weeks or even months after a crisis. The federal financial response to the COVID-19 pandemic provides a lens through which we can examine a typical ad hoc federal crisis response. Comparatively, the federal response to COVID-19 was relatively swift. The Coronavirus Aid, Relief, and Economic Security Act (CARES Act), ${ }^{41}$ which was enacted on March 27, 2020, included numerous provisions to help both individuals and businesses during the early stages of the pandemic. Although the CARES Act arrived in an unusually timely fashion, ${ }^{42}$ its primary problem was that it did not sufficiently support state and local budgets. Additional federal assistance through the Federal Reserve, while important, also proved to be inadequate support at the state and local level.

The CARES Act provided small business interruption loans of up to $\$ 10$ million, the proceeds of which could be used for payroll support (including paid sick, medical, or family leave, and group health care benefit costs), employee salaries, rent or mortgage payments, utilities, and existing debt obligations. ${ }^{43}$ The Act also provided "recovery rebates" for individual tax filers ${ }^{44}$ with an estimated average payout of $\$ 1,523 .{ }^{45}$ The Act also contained, among other things, provisions designed to reduce or delay

\footnotetext{
${ }^{41}$ Coronavirus Aid, Relief, and Economic Security Act, Pub. L. No. 116-136, 134 Stat. 281 (2020) [hereinafter CARES Act].

42 Even the CARES Act, which was passed fairly quickly, was not signed into law until nearly two weeks after President Donald Trump declared the pandemic a national emergency. A Timeline of COVID19 Developments in 2020, AM. J. MANAGED CARE (Jan. 1, 2021), https://www.ajmc.com/view/atimeline-of-covid19-developments-in-2020 [https://perma.cc/DP46-L6MB]. Some government programs are designed to provide a more rapid response, such as the Disaster Relief Fund, which as of the end of fiscal year 2019 carried a balance of $\$ 29$ billion. William L. Painter, CONG. RSCh. SerV., R45484, The Disaster Relief Fund: Overview AND ISSUES ii (2020). However, this too is an inadequate resource. Designed to help manage the costs of natural disasters, it is often dwarfed by yearly cyclone costs alone, which average $\$ 21.5$ billion in damage for each event. Fast Facts: Hurricane Costs, NAT'L OCEANIC \& ATMOSPHERIC ADMIN., OFF. FOR COASTAL MGMT., https://coast.noaa.gov/states/fastfacts/hurricane-costs.html [https://perma.cc/CCJ6-47JV]. Unlike the Disaster Relief Fund, however, the fund proposed here would not be circumscribed by a narrow definition of "disaster" as a natural catastrophe and would not be subject to a presidential determination of an emergency.

43 CARES Act $\S 1102(a)$.

44 CARES Act $\S 2201$.

45 Garrett Watson, Taylor LaJoie, Huaqun Li \& Daniel Bunn, Congress Approves Economic Relief Plan for Individuals and Businesses, TAX FOUND. (Mar. 30, 2020), https://taxfoundation.org/cares-actsenate-coronavirus-bill-economic-relief-plan/ [https://perma.cc/W2BW-6EE4].
} 
business taxes ${ }^{46}$ and personal taxes, ${ }^{47}$ provisions to manage medical equipment and drug supplies, ${ }^{48}$ and provisions for "severely distressed sectors"- passenger air carriers, cargo air carriers, and other businesses which incurred losses to the point that continued operations were "jeopardized." 49

As previously noted, however, the ex post CARES Act did not adequately support state and local budgets and may have a long-term impact on the U.S. economy. For one, as in the 2007 Financial Crisis, ${ }^{50}$ the bailouts for severely distressed businesses came with strings attached: the Secretary of the Treasury was authorized by the legislation to enter into contracts with businesses receiving funding through the loan program so that, depending on the financial success of the eligible business, the government could aid in the business's further gains through various mechanisms such as warrants, stock options, and common or preferred stock. ${ }^{51}$ These "strings" thus cut into state and local business profits during a time when local economies were already deeply hurting. Moreover, the Congressional Budget Office estimates that the previously unplanned-for allocation of federal funds through the CARES Act will increase federal deficits by about $\$ 1.7$ trillion over the 2020-2030 period, with a $\$ 988$ billion increase in mandatory expenditures under the Act, a $\$ 408$ billion decrease in revenues, and a $\$ 326$ billion increase in "discretionary" expenditures. ${ }^{52}$ Together, these effects may have a long-term impact on the health of the U.S. economy.

46 CARES Act $\$ \$ 2301-2308$.

47 CARES Act $\$ 2102$.

48 CARES Act $\S 3102$.

49 CARES Act $\S 4003$.

50 In the Emergency Economic Stabilization Act of 2008, Treasury was authorized to purchase "troubled asset[s]" from publicly traded financial institutions on the condition that Treasury receive "a warrant giving the right to the Secretary to receive nonvoting common stock or preferred stock in such financial institution.” Emergency Economic Stabilization Act of 2008, Pub. L. No. 110-343, 122 Stat. $3765 \S 113(\mathrm{~d})(1)$. The purpose of the requirement was to "provide for reasonable participation by the Secretary, for the benefit of taxpayers, in equity appreciation in the case of a warrant or other equity security, or a reasonable interest rate premium, in the case of a debt instrument," and to "provide additional protection for the taxpayer against losses from sale of assets by the Secretary under this Act and the administrative expenses of the TARP." Id. § 113(d)(2).

51 CARES Act $\S 3102(\mathrm{~d})(2)$.

52 Letter from Phillip L. Swagel, Director, Cong. Budget Off., to Hon. Mike Enzi, Chairman, Comm. on the Budget 1-2 (Apr. 27, 2020). The Act provided for expenditures of over $\$ 2$ trillion, but the Congressional Budget Office (CBO) notes:

[T]he projected cost is less than [ $\$ 2$ trillion] because some of that assistance is in the form of loan guarantees, which are not estimated to have a net effect on the budget. In particular, the act authorizes the Secretary of the Treasury to provide up to $\$ 454$ billion to fund emergency lending facilities established by the Board of Governors of the Federal Reserve System. Because the 
In addition to interventions like the CARES Act, current federal monetary policy can also play an important - though incomplete-role in managing widescale crises. The Federal Reserve has assisted in the COVID19 response through a wide variety of ad hoc mechanisms. These mechanisms include cutting the target for the federal funds rate to $0 \%$ from $0.25 \%$ (which helps reduce borrowing costs for mortgages, car loans, student loans, and other types of debt); purchasing securities in the market (hearkening back to the "quantitative easing" strategies employed during the 2007 Financial Crisis, in which the Fed purchased trillions in securities such as mortgage-backed instruments); ${ }^{53}$ securities lending; supporting money market mutual funds; and direct lending to financial institutions, major employers, and state and municipal governments. ${ }^{54}$ Such mechanisms are designed to alleviate financial and economic pressures by providing capital and liquidity that sustain financially stressed businesses during widescale crises.

The Federal Reserve has also attempted to help local governments more directly through the Municipal Liquidity Facility (MLF), a funding mechanism established by the CARES Act to help provide liquidity to state and local governments affected by the COVID-19 crisis. ${ }^{55}$ Under the program, the facility is available to any state or city with more than 250,000 residents or county with more than 500,000 residents with a strong credit rating. ${ }^{56}$ The program provides up to $\$ 500$ billion in funding through the purchase of short-term debt. ${ }^{57}$ The debt is priced by reference to a floating rate in addition to a "fixed spread" derived from the debt's rating. ${ }^{58}$ Debt proceeds must be used to help manage liquidity problems arising from COVID-19, including cash flow effects resulting from deferred tax filings..$^{59}$

Nevertheless, by November 30, 2020, the MLF was primarily utilized by only two issuers, the state of Illinois and the New York Metropolitan

\footnotetext{
income and costs stemming from that lending are expected to roughly offset each other, CBO

estimates no deficit effect from that provision.

54 For a summary of the Federal Reserve's efforts, see Jeffrey Cheng, Tyler Powell, Dave Skidmore \& David Wessel, What's the Fed Doing in Response to the COVID-19 Crisis? What More Could It Do?, BROOKINGS (Jan. 25, 2021), https:/www.brookings.edu/research/fed-response-to-covid19/ [https:// perma.cc/5XRL-S7LZ].

$55 \mathrm{Id}$.

56 FAQs: Municipal Liquidity Facility, FED. RSRV. BANK N.Y., https://www.newyorkfed.org/ markets/municipal-liquidity-facility/municipal-liquidity-facility-faq [https://perma.cc/E8CP-9E4R].

$58 \mathrm{Id}$.

59 Id.
} 
Transportation Authority ${ }^{60}$ and for relatively small amounts totaling only $\$ 1.65$ billion. ${ }^{61}$ The Federal Reserve viewed the program primarily as a mechanism to reassure investors who would be "comforted that the Fed was standing by to meet the liquidity needs of state and local governments." ${ }_{62}$ The program's critics, however, argue that it was too restrictive, with eligible issuers generally limited to large cities and counties. ${ }^{63}$ Issuers also reportedly found the interest rates set by the Federal Reserve to be unattractively highwith one estimate suggesting $97 \%$ of eligible cities, counties, and states could be functionally excluded from the program because of pricing ${ }^{64}$-and the maximum debt maturity to be unattractively short. ${ }^{65}$ The MLF was also a fairly short-term program with the Federal Reserve buying state and local debt instruments only up to December $31,2020 .{ }^{66}$ Ultimately, while federal financial support during the COVID-19 pandemic has been deeply needed, federal efforts have proved to be insufficient: state and local governments "have been battered by pandemic-related costs and collapsing tax revenues,

\footnotetext{
${ }^{60}$ Colby Smith \& Brooke Fox, US Businesses Race to Tap Fed Lending Before Year-End Expiry, Fin. TIMES (Dec. 18, 2020), https://www.ft.com/content/c9cd9a01-4cbe-45e4-b369-ee796f11730e [https://perma.cc/7KEJ-F4X5]; Yvette Shields, Illinois Pockets \$2 Billion Fed Municipal Liquidity Facility Loan, BOND BUYER (Dec. 18, 2020, 8:09 AM), https://www.bondbuyer.com/news/illinoispockets-2b-fed-mlf-loan [https://perma.cc/Q3XA-M7UK].

61 Bd. of Governors of the Fed. RSRV. Sys., Periodic Report: Update on Outstanding LENDING FACILITIES AUTHORIZED BY THE BOARD UNDER SECTION 13(3) OF THE FEDERAL RESERVE ACT 6 (2020), https://www.federalreserve.gov/monetarypolicy/files/pdcf-mmlf-cpff-pmccf-smccf-talf-mlfppplf-msnlf-mself-msplf-nonlf-noelf-12-11-20.pdf [https://perma.cc/2EFL-L4R9]. The facility was reportedly used again at the end of its expiry date for a total of $\$ 6.4$ billion. Smith \& Fox, supra note 60.

${ }^{62}$ Sarah Wynn, Disagreement on the Role of the Fed's Municipal Liquidity Facility, BOND BUYER (Sept. 17, 2020), https://www.bondbuyer.com/news/disagreement-on-the-role-of-the-feds-municipalliquidity-facility [https://perma.cc/5EGT-RB37].

63 Popular Democracy, Aiming to Underachieve: How a Federal Reserve Lending Program For Local Governments Is Designed to FALl Short 2 (2020), https://www.populardemocracy.org/sites/default/files/Aiming\%20to\%20Underachieve $\% 20-\% 20 \mathrm{Fed}$ \%20Up\%20White\%20Paper\%20June\%202020.pdf [https://perma.cc/CH7N-LF8U].

${ }^{64} I d$. at 3.

$65 I d$. at 6.

${ }^{66}$ FAQs: Municipal Liquidity Facility, supra note 56. Other criticisms include concerns that the program represents a misallocation of credit, with the Federal Reserve

reallocate[ing] purchasing power away from other entities in the market to those whose bonds the Fed purchases. The cost to society is the difference between the value of the projects pursued by state and local government with those resources and the value of the projects other entities could have pursued with those same resources.

Alexander William Salter, The Fed's State and Municipal Lending Is a Bad Idea, HILl (June 12, 2020, 8:00 PM), https://thehill.com/opinion/finance/502505-the-feds-state-and-municipal-lending-is-a-badidea [https://perma.cc/U56M-8FGX].
} 
[and] have already cut more than 1.3 million jobs." ${ }^{67}$ Indeed, even the $\$ 900$ billion relief package proposed in December 2020 would not be enough to support people until the economy rebounds, as is expected to happen after the distribution of COVID-19 vaccines. ${ }^{68}$

Finally, emergency federal support through deficit spending, like the CARES Act and Federal Reserve mechanisms, has another flaw. Unless funds are set aside for moments of crisis, emergency appropriations typically borrow from the future (and future generations) to pay for present expenses. ${ }^{69}$ With deficit spending, future generations inherit a burden without having had the opportunity to vote on and approve it. By contrast, the resilience fund described below borrows from the present (and current taxpayers) to pay for future expenses. Therefore, with respect to intergenerational justice, a resilience fund creates a more just option than deficit spending in the sense that the polity is able to vote on and approve or disapprove of measures that limit current expenditures.

\section{B. State Rainy Day Funds}

Unfortunately, states have limited options to mitigate problems arising from budget shortfalls ${ }^{70}$ and, like federal efforts, these options are often insufficient in the face of large-scale crises. States can reduce spending where possible and may also raise taxes. However, these are "procyclical policies that not only disrupt public services and increase taxpayers' burden, but also worsen recessions and slow economic recoveries." 71 Moreover, because demand for many of the costliest public services, such as education and social services, is fixed and inelastic, states may be limited in their ability to significantly reduce spending without dramatically limiting services through layoffs or other draconian measures. ${ }^{72}$

\footnotetext{
67 Jim Tankersley \& Ben Casselman, A \$900 Billion Plan Would Help the Economy, but Not Fix It, N.Y. TIMES (Dec. 20, 2020), https://www.nytimes.com/2020/12/04/business/economy/congress-stimulus -economy-impact.html?searchResultPosition=2 [https://perma.cc/X9TJ-LABR].

68 Id.

69 Deficit spending, by definition, means that the costs of legislation are not covered by existing tax revenues. The Committee for a Responsible Federal Budget estimates the deficit impact of legislation related to COVID-19 to be about \$3.4 trillion. Breaking Down \$3.4 Trillion in COVID Relief, ComM. FOR A RESPONSIBLE FED. BUDGET (Jan. 7, 2021), https://www.crfb.org/blogs/breaking-down-3-4-trillion -covid-relief [https://perma.cc/UD5U-Y3UX].

70 Bo Zhao, Saving for a Rainy Day: Estimating the Appropriate Size of U.S. State Budget Stabilization Funds 1 (Fed. Rsrv. Bank of Bos., Working Paper No. 14-12, 2014), https:/www. bostonfed.org/-/media/Documents/Workingpapers/PDF/wp1412.pdf [https://perma.cc/RTR7-FNAQ].

71 Id.

72 Bo Zhao \& David Coyne, Walking a Tightrope: Are U.S. State and Local Governments on a Fiscally Sustainable Path? 1-2, 15, 31 tbl.3 (Fed. Rsrv. Bank of Bos., Working Paper No. 13-18, 2013),
} 
In addition to their limited ability to reduce spending, states also have a limited ability to maintain services through deficit spending. Almost all states have balanced budget amendments which prohibit state governments from going into debt to finance government expenditures. ${ }^{73}$ Further, political expediency may compel state governments to establish balanced budgets to determine political survival. Governors and legislators cannot successfully run for reelection with a budget in deficit. ${ }^{74}$ Crises also tend to have powerful countercyclical effects: not only do revenues decrease, but service demands also rise with the decrease in revenues and resources. ${ }^{75}$ State tax structures exacerbate this effect as states are increasingly relying "on narrower, and often more elastic tax basis such as personal income, and higher nominal rates." ${ }^{\prime \prime 6}$

Local governments are also limited in the ways in which they can raise revenue and cut spending in the event of a crisis requiring significant economic resources. Because states have taken on greater responsibility for funding high-cost social services like health care, state budget gaps may lead localities to try to make up the difference by shifting resources from other

https://www.bostonfed.org/publications/research-department-working-paper/2013/walking-a-tightropeare-us-state-and-local-governments-on-a-fiscally-sustainable-path.aspx [https://perma.cc/N9F9-TXJR] (finding evidence that education, social services and income maintenance, public safety, transportation, and government administration expenditures "are income inelastic and that they are necessary goods for the public").

73 The exact number is debatable, depending on how explicit one reads the applicable amendment or statutory provision:

The National Conference of State Legislatures (NCSL) has traditionally reported that 49 states must balance their budgets, with Vermont being the exception. Other authorities add Wyoming and North Dakota as exceptions, and some authorities in Alaska contend that it does not have an explicit requirement for a balanced budget. Two points can be made with certainty, however: Most states have formal balanced budget requirements with some degree of stringency, and state political cultures reinforce the requirements.

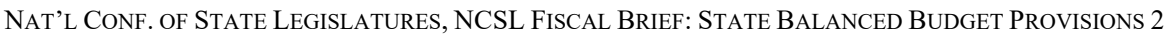
(2010), https://www.ncsl.org/documents/fiscal/StateBalancedBudgetProvisions2010.pdf [https://perma. cc/7LQQ-SSFS].

74 Gary C. Cornia \& Ray D. Nelson, Rainy Day Funds and Value at Risk, STATE TAX Notes 563, 563 (2003), https://www.urban.org/sites/default/files/publication/58781/1000606-Rainy-Day-Funds-and -Value-at-Risk.PDF [https://perma.cc/9T3T-CUCJ].

75 Richard Mattoon, Creating a National State Rainy Day Fund: A Modest Proposal to Improve State Fiscal Performance 4 (Fed. Rsrv. Bank of Chi., Working Paper No. 2003-20, 2003), https://www. chicagofed.org/digital_assets/publications/working_papers/2003/wp2003-20.pdf [https://perma.cc/3VJC-MPFH].

76 Id. Mattoon notes that states appear "reluctant to 'fix' their tax structures to better manage volatility. In addition, it is unclear that revenue volatility is necessarily a bad thing if states are willing to create budget stabilization tools. Efforts to broaden major tax bases, such as subjecting services to sales taxation, have seen little progress." $I d$. 
programs or, when possible, by increasing taxes. ${ }^{77}$ Local governments, however, face funding challenges created by state limitations on their ability to raise revenue. Forty-two states place limitations on local governments' property tax powers, and "the number of restrictions has expanded extensively since [the] 1990s." 78 Local governments also have increasing federal and state mandates, which are not adequately funded through federal and state aid, to provide services ranging from "criminal justice and public safety, health and human services, transportation and infrastructure, to administration of elections and property assessments." 79 Thus, like state governments, local governments have relatively inelastic budgets.

In the face of rising costs and limited options for increasing revenues, almost all U.S. states have set up "rainy day funds" to help balance their budgets in the event of a shortfall. ${ }^{80}$ Prior to COVID-19, state funds had reached a record $\$ 74.9$ billion in budget reserves. ${ }^{81} \mathrm{~A}$ Pew study estimates that states could have continued government operations on these funds for a median of 27.9 days (equivalent to $7.7 \%$ of total annual spending). ${ }^{82}$ The insufficiency of rainy day funds is apparent from two crises in the past fifteen years: the Financial Crisis of 2007-2008 and the ongoing COVID-19 pandemic.

State governments suffered a shortfall of approximately $\$ 690$ billion in the five years following the Financial Crisis. ${ }^{83}$ Some states made considerable use of those funds during the Financial Crisis and the "Great Recession" that followed. According to Marlowe, "rainy day funds have

77 See State and Local Finance Expenditures, URBAN INST., https://www.urban.org/policycenters/cross-center-initiatives/state-and-local-finance-initiative/state-and-local-backgrounders/stateand-local-expenditures [https://perma.cc/L4U8-SUHU] (showing public welfare spending, including Medicaid spending, rising from $13 \%$ of state and local spending in 1977 to $22 \%$ in 2017).

78 JOEl GRIFFITH, JONATHAN HARRIS \& EMILIA ISTRATE, DOING MORE WITH LESS: STATE REVENUE Limitations \& MANDATES On COUnTy FinANCES 1 (Nat'l Ass'n of Counties Pol'y Rsch. Paper Series Issue 5, 2016), https://www.naco.org/sites/default/files/documents/Doing\%20More\%20with\%20Less_ Full\%20Report.pdf [https://perma.cc/V2C9-36KK].

79 Id.

80 Barb Rosewicz, Justin Theal \& Joe Fleming, States' Financial Reserves Hit Record Highs, PEW CHARITABLE TRS. (Mar. 18, 2020), https://www.pewtrusts.org/en/research-and-analysis/articles/ 2020/03/18/states-financial-reserves-hit-record-highs [https://perma.cc/G59A-8587]. The authors note that "[s]tates use reserves and balances to manage budgetary uncertainty, including revenue forecasting errors, budget gaps during economic downturns, and other unforeseen emergencies, such as natural disasters. This financial cushion can soften the need for severe spending cuts or tax increases when states need to balance their budgets." $I d$.

81 Id.

$82 \mathrm{Id}$.

83 Childress et al., supra note 8 (citing EliZABETH MCNiCHOL, MiCHAEL LEACHMAN \& JOSHUAH Marshall, Ctr. on Budget \& Pol'y Priorities, States NeEd SignifiCANTLy MORE Fiscal RELIEF TO SLOW THE EMERGING DEEP RECESSION 12-13 (2020), https:/www.cbpp.org/sites/default/files/atoms/ files/4-14-20sfp.pdf [https://perma.cc/EZ3A-Z6TD]). 
been the best (and in some cases the only) tool" for states in mending the destruction of states' economies following the Great Recession. ${ }^{84}$ As noted in a McKinsey report, however, "[t]wenty-eight states drained their rainyday funds to a point where they had less than a week's worth of operating costs; 17 used them entirely." 85 For other states, flaws in the design of their rainy day funds discouraged the use of the funds, despite the severity of the crisis. Missouri's constitution, for example, requires that any withdrawals from the state rainy day fund be paid back within three years, with interest, and that the state must redeposit in each of those years at least a third of the amount withdrawn. ${ }^{86}$ As a result, states saw significant reductions in health, education, and other social services from the Financial Crisis. ${ }^{87}$ With the COVID-19 pandemic coming soon after, states were again pushed to the brink.

Given the severity of COVID-19's financial implications, states were faced with a clear need to draw down on their rainy day funds. In Ohio, for example, the state's rainy day fund provided the state with "financial firepower to withstand the fiscal assault brought on by COVID-19," and, because of the fund, the state did not have to rely on tax increases or federal loans to cover the expenses. ${ }^{88}$ As with the Financial Crisis, however, the funds' limited sizes have hampered their effectiveness. As shown in the graphs below, ${ }^{89}$ funds from state rainy day funds cover only about $8.5 \%$ of states' fiscal needs in aggregate. While rainy day funds were at historically high levels prior to the COVID-19 crisis, most (if not all) do not have sufficient funding to help states cover the losses from 2020 - let alone the

\footnotetext{
84 Justin Marlowe, What's the Point of Rainy Day Funds?, GovernING (June 2013), https://www.governing.com/archive/colpoint-of-rainy-day-funds.html [https://perma.cc/BRM6-YZRJ].

85 Childress et al., supra note 8.

86 Stephen Bailey, Brenna Erford, Kil Huh, AKshay Iyengar, Airlie loiaconi, Patrick Murray, Robert Zahradnik \& Alexandria Zhang, Pew Charitable Trs., When to Use State RAINY DAY FundS: WiTHDRAWAL POLICIES TO MITIGATE VOLATILITY AND PROMOTE STRUCTURALLY BALANCED BUDGETS 12-13 (2017), https://www.pewtrusts.org/ /media/assets/2017/04/when-to-usestate-rainy-day-funds.pdf [https://perma.cc/2AAU-HZLA].

87 In response to the 2007 Financial Crisis, "[m]ost states cut spending." Tracy Gordon, State and Local Budgets and the Great Recession, BROOKINGS (Dec. 31, 2012), https://www.brookings.edu/ articles/state-and-local-budgets-and-the-great-recession/ [https://perma.cc/US94-M9KX]. Cuts fell predominantly in education, health, and social services, where states also dedicate most of their budgets. Id.

88 The Buckeye InST., Policy Memo: Using the Rainy DAy Fund to Fight COVID-19's IMPACT 1 (2020), https://www.buckeyeinstitute.org/library/docLib/2020-04-15-The-Buckeye-InstituteStrategic-Use-of-Ohio-s-Rainy-Day-Fund-Along-with-Budget-Cuts-Would-Avoid-Tax-Increasespolicy-memo.pdf [https://perma.cc/KD8L-7YKP].

89 See NAT'L ASS'N OF State Budget OfFicers, The FisCAl Survey OF STATES 67 tbl.25, 69 figs.4 \& 5 (2019), https://higherlogicdownload.s3.amazonaws.com/NASBO/9d2d2db1-c943-4f1b-b7500fca152d64c2/UploadedImages/Fiscal\%20Survey/NASBO_Fall_2019_Fiscal_Survey_of_States_S.pdf [https://perma.cc/236E-DQDX].
} 
expected downturns in 2021 and beyond. Indeed, ten states tapped their rainy day funds within the first few months of the crisis. Some states' rainy day funds were so scant "that, even if they were entirely drained, there wouldn't be enough cash to help the states through a fine mist, much less a rainy day. ${ }^{90}$ Nevada, for example, quickly used all of the $\$ 401$ million in its rainy day fund to help cover the shortfall resulting from the pandemic, which for fiscal year 2020 alone is expected to range from $\$ 741$ million to $\$ 911$ million. ${ }^{91}$

Figure 1: U.S. State Rainy Day Fund Balances (Billions)

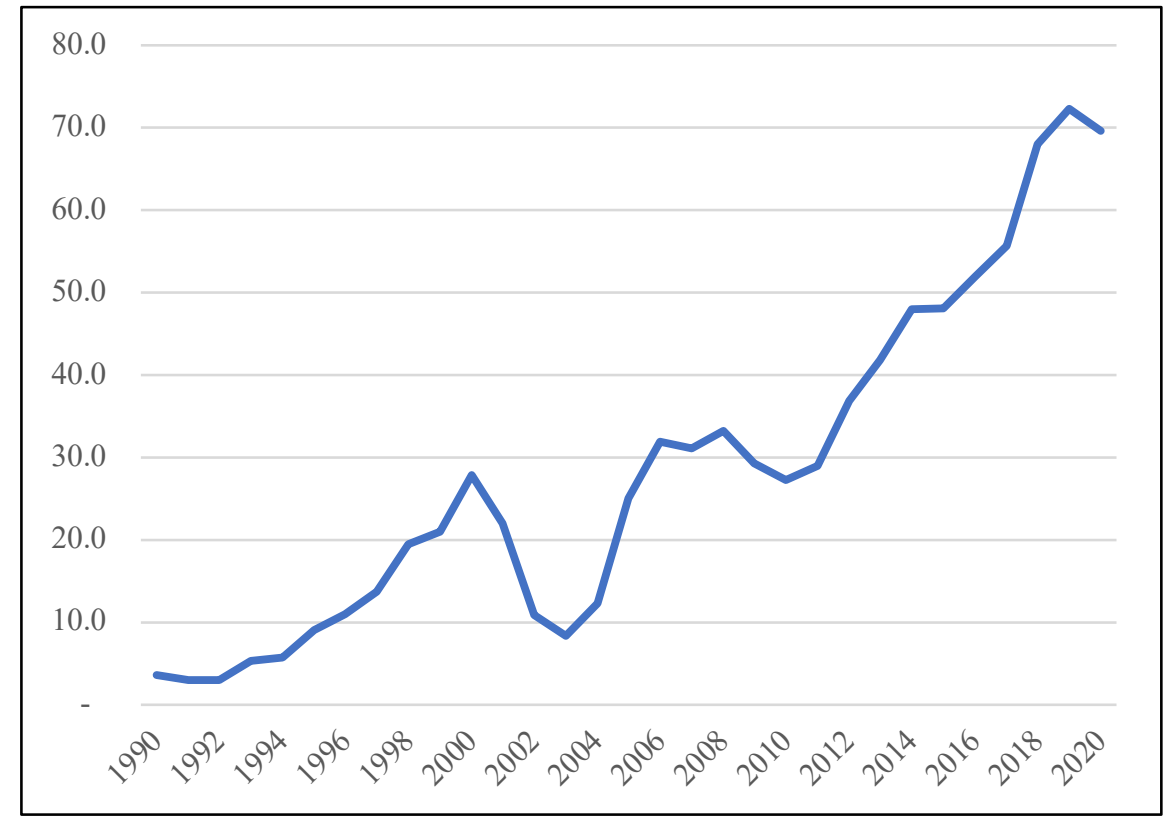

90 Katherine Barrett \& Richard Greene, The Draining of State Rainy Day Funds, ROUTE FIFTY (Oct. 13, 2020), https://www.route-fifty.com/finance/2020/10/draining-state-rainy-day-funds/169194/ [https:// perma.cc/4H8Q-6NLU].

91 Board Drains Nevada's Rainy Day Fund to Deal with Pandemic Financial Crisis, NeV. APPEAL (Feb. 24, 2021), https://www.nevadaappeal.com/news/2020/may/15/board-drains-nevadas-rainy-dayfund-to-deal-with-p/ [https://perma.cc/6PFW-HAMB]. 
Figure 2: U.S. State Rainy Day Fund Balances as Percentage of Total Expenditures

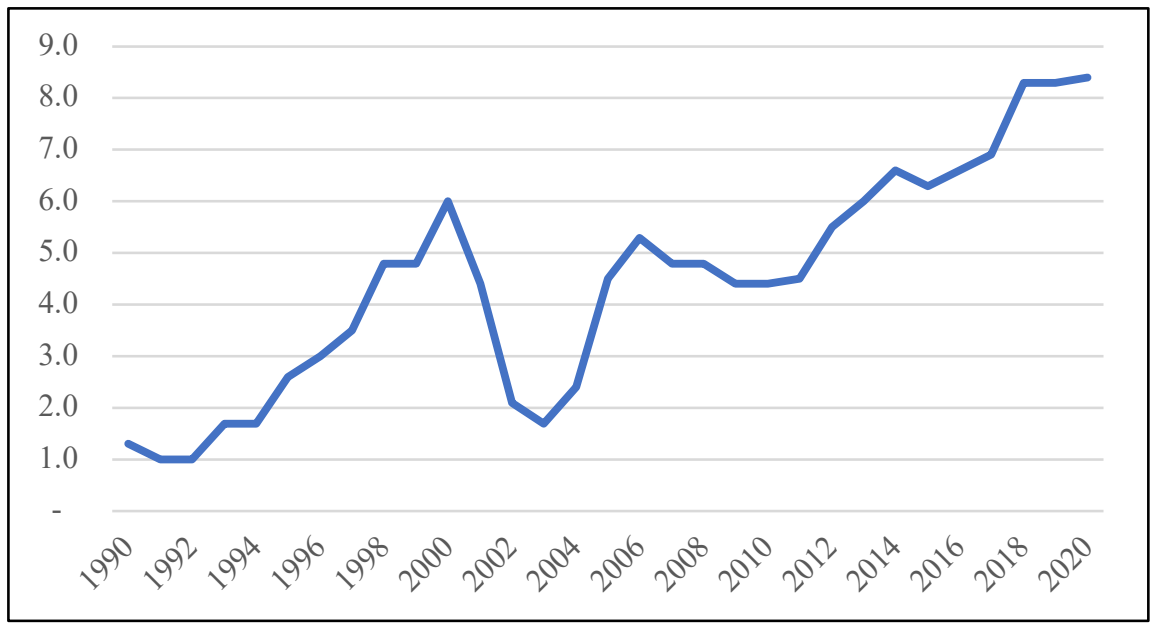

In an extensive review of the COVID-19 crisis and its impact on state and local budgets, taking into account the mitigating effect of state rainy day funds, a Federal Reserve Bank of Cleveland study suggests that income and sales revenues will decline by $\$ 54$ billion in fiscal year $2020 .{ }^{92}$ An additional $\$ 25$ billion to $\$ 137$ billion in revenue may be lost, depending on the speed of the recovery. ${ }^{93}$ Rainy day funds may reduce the loss to $\$ 21$ billion in 2020 and $\$ 4$ billion to $\$ 78$ billion in $2021 .{ }^{94}$ State rainy day funds thus provide significant mitigation, but not nearly enough to stave off a substantial diminution in essential governmental services.

In sum, the federal responses to COVID-19 and the Financial Crisis of 2007-2008 revealed that the federal government's crisis efforts are slow and inefficient at responding to local needs. Additionally, in the case of dramatic, large-scale crises like pandemics, national resources may also be insufficient. State rainy day funds may fill some gaps, but they are too small in size and are subject to political calculations that make it less likely that they would be used to manage crises in their early stages.

\footnotetext{
92 Stephan D. Whitaker, Fed. RSRV. Bank OF Cleveland, Estimates of State and Local GOVERNMENT REVENUE LOSSES FROM PANDEMIC MitigATION 1 (2020), https://www.clevelandfed.org/ newsroom-and-events/publications/cfed-district-data-briefs/cfddb-20200513-estimates-of-state-andlocal-government-revenue-losses-from-pandemic-mitigation.aspx [https://perma.cc/4VT6-KCQ5].

${ }_{93} I d$.

${ }^{94}$ Id.
} 


\section{DEVEloping A NATIONAL RESILIENCE Fund}

In a moment characterized by compounding crises and inadequate financial tools at every level, something more is needed. A resilience fund would go far in filling this gap. This Part describes how a national resilience fund, with subaccounts created for each state and territory, would help state and local governments respond to the crises that are likely to arise in the coming years. A national resilience fund could be based on a familiar, flexible structure that has already been in use for decades: the Unemployment Trust Fund. ${ }^{95}$ Such a structure would help insulate the resilience fund from local political pressures. It would also have the financial strength to help state and local governments absorb the costs associated with severe crises such as pandemics and natural disasters, thereby helping to preserve governmental legitimacy in times of severe social stress.

\section{A. Building a National Resilience Fund}

The concept of a national-level stabilization fund, designed to alleviate budget crises similar to the resilience fund proposed here, has been in use for decades in other countries. As with a resilience fund, governments use budget stabilization-oriented funds to help manage unexpected economic downturns. ${ }^{96}$ In the United States, the notion of creating a national fund that could absorb state and local budgetary shocks also has some precedent. In a 2003 publication, for example, Federal Reserve economist Richard Mattoon suggested a federal version of a rainy day fund, with separate subaccounts for each state, that could be deployed to respond to larger crises that current rainy day funds cannot manage. ${ }^{97}$

Mattoon identified a number of justifications for a national fund as opposed to simply increasing funding for state rainy day funds. ${ }^{98}$ The politics of rainy day funds, for example, present significant barriers to expanding existing state funds. ${ }^{99}$ A number of states already have relatively low caps on the amount of money that may be reserved in the rainy day fund; of the fortyone states with caps, nine restrict the fund to $5 \%$ or less of the state's total expenditures or revenues. ${ }^{100}$ Because the funds are typically part of the state

\footnotetext{
95 See infra Section III.A.1.

96 See, e.g., Xie Ping \& Chen Chao, The Theoretical Logic of Sovereign Wealth Funds 24 (June 16, 2009) (unpublished manuscript), https://ssrn.com/abstract=1420618 [https://perma.cc/X7T4-SZN5] (describing the use of sovereign wealth funds as, among other things, budget stabilization mechanisms).

97 See Mattoon, supra note 75, at 4.

98 Id. at 3-4.

99 Id. at 3.

100 TAX POL'Y CTR., BRIEFING BOOK 668 (2020), https://www.taxpolicycenter.org/sites/default/ files/briefing-book/tpc_briefing_book_2020.pdf [https://perma.cc/TPX8-REM9].
} 
constitution, increasing the fund's limits may require a change to the state constitution and would necessitate either an increase in tax or a decrease in services. ${ }^{101}$ With state budgets already struggling to meet current expenditures and facing budgetary headwinds as they move into the future, ${ }^{102}$ it seems unlikely that states could muster the political will to set aside funds that would otherwise be used on existing needs to prepare for future challenges. Such existing needs include dramatic increases in state Medicaid spending, which is now the greatest expense after $\mathrm{K}-12$ education. ${ }^{103}$ Additionally, pension costs also create significant challenges for state budgets. Unfunded pension benefits were the "most prominent, and fastestgrowing of a selection of future costs facing states as of 2013." 104 Despite the strong performance of the stock market in recent years, plan liabilities continue to outpace asset growth. The Pew Charitable Trusts estimates the total national funding gap to be around $\$ 1.37$ trillion. ${ }^{105}$ Finally, demographic change due to a long-term trend of slower population growth will limit economic growth and place additional pressures on state budgets. ${ }^{106}$ All of these factors reveal the limits of state rainy day funds and demonstrate the importance, if not the necessity, of providing an additional funding structure that can help respond to major crises. The following sections briefly outline a solution.

\section{Fund Structure}

A federal resilience fund could be created using a well-established model: the Unemployment Trust Fund (UTF). As part of the New Deal, the Federal Unemployment Tax Act of 1939 created an "Unemployment Compensation" (UC) program. ${ }^{107}$ The system was structurally federalist, with some funding provided by federal payroll taxes and other funding

\footnotetext{
101 For a detailed review of the state provisions governing rainy day funds, see NAT'L CONF. OF State Legislatures, Rainy Day Fund StRuctures 8 (2018), https://www.ncsl.org/Portals/1/ Documents/fiscal/RDF_2018_Report.pdf [https://perma.cc/MB4G-C8YF].

102 NAT'L ASS'N OF STATE BUDGET OFFICERS, supra note 89, at vii.

103 Fiscal 50: State Trends and Analysis, Pew CharitaBle TrS. (Feb. 17, 2021), https://www. pewtrusts.org/en/research-and-analysis/data-visualizations/2014/fiscal-50\#ind0 [https://perma.cc/YGF2ZJME].

104 Id.

105 David Draine, Keith Sliwa \& Emma Wei, Public Pension Investments Largely Recover After Pandemic-Related Slide, Pew Charitable TrS. (Aug. 25, 2020), https://www.pewtrusts.org/en/ research-and-analysis/articles/2020/08/25/public-pension-investments-largely-recover-after-pandemicrelated-slide [https://perma.cc/8DNY-GSA3].

106 Fiscal 50: State Trends and Analysis, supra note 103.

107 Julie M. WhitTaKer, Cong. Rsch. SERV., RS22954, The Unemployment Trust Fund (UTF): STATE INSOLVENCY AND FEDERAL LOANS TO STATES 1 (2018).
} 
through state taxes. ${ }^{108}$ These funds were (and still are) deposited into the UTF, which pays out benefits to help manage spikes in unemployment during economic crises. ${ }^{109}$ The UTF operates countercyclically, building funds in prosperous times and paying out in lean times:

When the economy grows, UC program revenue rises through increased tax revenues. At the same time, UC program spending falls because fewer workers are unemployed. The effect of collecting more taxes while decreasing spending on benefits dampens demand in the economy. It also creates a surplus of funds, or a reserve fund, for the UC program to draw upon during a recession. These reserve balances are credited in the state's account within the UTF. During an economic slowdown or recession, UC tax revenue falls and UC program spending rises as more workers lose their jobs and receive UC benefits. The increased amount of UC payments to unemployed workers dampens the economic effect of lost earnings by injecting additional funds into the economy. ${ }^{110}$

States have varying levels of "solvency" in the fund;"11 some states have more funds available than they would typically need to pay claims in a given

108 The Federal Unemployment Tax Act imposes "on every employer" a $6 \%$ tax on total wages. 26 U.S.C. $\$ 3301$. Most of the funding comes from the states. JULIE M. WhITTAKER, CONG. RSCH. SERV., R44527, UNEMPLOYMENT COMPENSATION: THE FundAMENTALS OF THE FEDERAL UNEMPLOYMENT TAX (FUTA) 1 (2016) (explaining that during "periods of economic expansion or stability, states fund approximately $90 \%$ of all UC expenditures - as almost all of the benefits are state financed by state unemployment taxes").

109 WHITTAKER, supra note 107.

$110 \mathrm{Id}$.

111 The U.S. Department of Labor reports that, as of February 2020, the solvency levels of thirty-one states are "greater than or at the recommended minimum solvency standard." U.S. DEP'T OF LABOR, OFF. OF UNEMPLOYMENT INS., Div. OF FISCAL \& ACTUARIAL SERVS., STATE UNEMPLOYMENT INSURANCE: TRUST FUND SOLVENCY REPORT 2-3 (2020), https://oui.doleta.gov/unemploy/docs/trustFundSolv Report2020.pdf [https://perma.cc/RZ64-L7H3]. Twenty-two states and jurisdictions had solvency levels below the recommend standard. $I d$. Solvency can be determined by several different methods. The Department of Labor uses a method by which they calculate the Reserve Ratio for a state:

The simplest solvency measure called the Reserve Ratio is derived by taking the trust fund balance and dividing by the state's total wages paid for the year.... This measure can be compared against the level of benefits paid in the year divided by the same yearly wages- this ratio is referred to as the Benefit Cost Rate. A common comparison is to take the highest Benefit Cost Rate in the state's history and compare it to the Reserve Ratio, or to take the average of the three highest Benefit Cost Rates in the last twenty years and compare that to the Reserve Ratio (this is called the Average High Cost Multiple). In the latter case, values greater than one (Reserve Ratio divided by Average Benefit Cost Rate) are considered the minimum level for adequate state solvency going into a recession....

Id. 
year. ${ }^{112}$ In cases in which states do not have sufficient funds, they are able to borrow from the federal government under a loan program. ${ }^{113}$

A similar countercyclical model could be employed for a national resilience fund, with taxes collected during "normal" times and funds spent during crises. States have put in place a wide variety of regulations on how rainy day funds are created, funded, drawn down, and replenished. ${ }^{114}$ Withdrawal from a rainy day fund is triggered by adverse events including economic downturns, health crises, and natural disasters, or simply budget shortfalls. ${ }^{115}$ As with rainy day funds, states would need to develop procedures for determining resilience fund mechanisms and withdrawals. As described below, creating specific budgetary triggers - and coordinating their use with the rainy day fund - would help ensure the fund is used as intended.

\section{Funding Mechanisms}

Rainy day funds are typically funded through year-end budget surpluses; tax revenues exceeding a certain amount; and proceeds from the sale of oil, gas, or mineral rights; among many other methods. ${ }^{116}$ Similar to the UTF, a national resilience fund need not require a specific source of funds, only that the account be built up to a specific threshold-for example, $15 \%$ of prior year expenditures ${ }^{117}$ - through contribution rules that would take a very small percentage of $1 \%-1.5 \%$ of general fund revenues. To facilitate the buildup of funds, a national wealth tax ${ }^{118}$ applied to very large fortunes over a certain threshold could provide additional funding. ${ }^{119}$

\footnotetext{
112 WHITTAKER, supra note 107 , at 9 tbl.2.

$113 \mathrm{Id}$. at 4.

114 See generally NAT'L CONF. OF STATE LEgISLATURES, supra note 101 (outlining various state differences in rainy day fund formation).

115 See id. at 8-23 (listing methods of withdrawal and events that trigger withdrawal from rainy day funds by each state).

116 See generally id. (listing methods of deposit to rainy day funds by each state).

117 Mattoon suggests such an amount for his rainy day fund, but given the severity of crises state and local governments may face, the total amount may need to be higher. Mattoon, supra note 75, at 14 .

118 See, e.g., Ari Glogower, Taxing Inequality, 93 N.Y.U. L. REV. 1421, 1486 (2018) (arguing that a wealth tax would be justified because "a constraint on economic inequality may in fact be necessary to preserve individual autonomy.... [U]nder the relative economic power theory excessive economic inequality suppresses the preferences of those with less economic power").

119 Saez and Zucman, for example, model a wealth tax for fortunes of $\$ 50$ million or more. Emmanuel Saez \& Gabriel Zucman, Progressive Wealth Taxation, BROOKINGS PAPERS ON ECON. ACTIVITY, Fall 2019, at 437, 440-41, https://www.brookings.edu/wp-content/uploads/2020/10/SaezZuchman-final-draft.pdf [https://perma.cc/VGZ7-Z6WE].
} 


\section{Withdrawal Mechanisms}

Withdrawal provisions define the circumstances under which funds may be drawn down. A withdrawal policy for a national resilience fund would allow for withdrawal of funds during defined severe budget crises caused by major shocks such as the COVID-19 pandemic. Among other purposes, a withdrawal policy may allow for withdrawals in the event of revenue shortfalls, revenue growth below a certain trend, general economic downturns, and health or safety emergencies. ${ }^{120}$ Clear rules would maintain state incentives to manage their budgets wisely, and withdrawal restrictions should limit the amount that may be withdrawn in any given year to ensure that funds are available for additional unexpected crises. For example, as with rainy day funds, the fund may have a rule that only $33 \%$ may be withdrawn in a given year, with up to $50 \%$ available if extreme conditions are met. ${ }^{121}$

\section{Managing the Fund}

As with the UTF, a national resilience fund could be managed through the U.S. Treasury. The U.S. Treasury has the expertise and capacity to provide necessary administrative services and has years of experience with analogous funds. ${ }^{122} \mathrm{~A}$ federally managed fund has another benefit: it would limit the temptation presented by a large state fund to use the money for politically advantageous but inappropriate expenditures - a temptation that would seem to grow in proportion to the size of the fund. Strong structural and governance protections are necessary to provide adequate insulation of the fund from political pressures. The federalist structure of a federally managed state account would also help insulate a national fund from federal officials who would be prevented from accessing the state funds for federal purposes. Likewise, state officials would also be prevented from accessing the funds directly, as the fund would only pay out in defined circumstances. This shelter from both federal and state political pressures would allow the fund to accumulate larger reserves without creating a temptingly large, statecontrolled fund. ${ }^{123}$ Importantly, however, a national resilience fund would

\footnotetext{
120 See supra notes 114-115 and accompanying text.

121 In his discussion of a national rainy day fund, Mattoon suggests that states "should be permitted to withdrawal up to half of their existing balance in a given year" but should have to show severe economic need through measures such as "a drop in real revenue over the preceding year or an increase in unemployment by $1 \%$ or more or a decline in personal income." Mattoon, supra note 75, at 18 .

${ }^{122}$ Such funds could be administered through the Office of Fiscal Service, which "oversees the development and implementation of policies relating to the government's cash management, operations, investment and administration of trust funds, payments, collections, and debt collections." Fiscal Service, U.S. DEP'T OF THE TREASURY, https://home.treasury.gov/about/offices/domestic-finance/fiscal-service [https://perma.cc/A59K-L88D].

${ }^{123}$ Mattoon, supra note 75, at 4.
} 
provide for state fiscal autonomy while not supplanting important existing federal resources such as the Unemployment Trust Fund, the Disaster Relief Fund, and - in cases where national resources must be coordinatedemergency legislation and appropriations.

\section{CONCLUSION}

At the beginning of the COVID-19 pandemic, state rainy day funds held approximately $\$ 75$ billion in assets. ${ }^{124}$ The pandemic is expected to create budget shortfalls of over $\$ 555$ billion for fiscal years 2020-2022 alone. ${ }^{125}$ The amount of funds available for state governments will not be enough to meet current budget needs, let alone help manage inevitable crises in the coming years. A national resilience fund could be a key fiscal tool in helping states manage the black elephant risks associated with climate change, economic dislocation, pandemics, and systemic injustice.

While specific details would need to be developed and negotiated, the concept of the national fund sketched out here would dramatically improve the resiliency of state and local finances in the face of serious crises. A fund that is built up over time would be able to mechanically and painlessly provide assistance to states without simply shifting costs to the federal government, as would be the case in a direct federal bailout. Federal assistance in a crisis is not certain, and, as Mattoon notes, "[t]he federal government is often in no better fiscal shape in a recession than the states and is likely to be grudging in helping states out of a bind." ${ }^{126}$ A national resilience fund with separate state accounts would motivate the federal government to provide state and local support during crises, as the funds would not be eligible for allocation at the federal level.

Finally, a national fund would benefit the federal government by "smoothing state fiscal reaction to recessions," which could "reduce the drag that state tax increases or expenditure cuts might have on the national economy." ${ }^{27}$ While it would not solve the long-term structural challenges involved in raising revenues and complying with partially funded mandates, a national fund would at least provide a shock absorption mechanism for state and local governments that provide many of the services essential to legitimate governmental function. Such an ex ante fund would thus help

\footnotetext{
124 Rosewicz et al., supra note 80.

125 Elizabeth MCNichol \& Michael Leachman, Ctr. On Budget \& Pol'y Priorities, States COntinue to Face Large Shortfalls Due to COVID-19 EFFECTS 3 (2020), https://www.cbpp.org/ sites/default/files/atoms/files/6-15-20sfp.pdf [https://perma.cc/B34M-SXXT].

126 Mattoon, supra note 75 , at 4.

${ }^{127}$ Id.
} 
retain government legitimacy during future, inevitable crises due to climate change, economic dislocation, pandemics, and systemic injustice. 